\title{
NATION, NATIONALISM AND THE PARTITION OF INDIA: TWO MOMENTS FROM HINDI FICTION*
}

\author{
Bodh Prakash \\ Ambedkar University, Delhi
}

\begin{abstract}
This paper traces the trajectory of Muslims in India over roughly four decades after Independence through a study of two Hindi novels, Rahi Masoom Reza's Adha Gaon and Manzoor Ehtesham's Sookha Bargad. It explores the centrality of Partition to issues of Muslim identity, their commitment to the Indian nation, and how a resurgent Hindu communal discourse particularly from the 1980s onwards "otherizes" a community that not only rejected the idea of Pakistan as the homeland for Muslims, but was also critical to the construction of a secular Indian nation.
\end{abstract}

Keywords: Manzoor Ehtesham, Partition in Hindi literature, Rahi Masoom.

\section{RESUMEN}

Este artículo estudia la presencia del Islam en India en las cuatro décadas siguientes a la Independencia, según dos novelas en hindi, Adha Gaon, de Rahi Masoom Reza y Sookha Bargad, de Manzoor Ehtesham. En ambas la Partición es el eje central de la identidad musulmana, que en todo caso mantiene su fidelidad a la nación india. Sin embargo, el discurso del fundamentalismo hindú desde la década de 1980 ha ido alienando a esta comunidad, que no solo rechazó la idea de Paquistán como patria de los musulmanes, sino que fue fundamental para mantener la neutralidad religiosa del estado en India.

Palabras Clave: Manzoor Ehtesham, Partición en literatura hindi, Rahi Masoom. 
The Indian anti-colonial struggle culminated in the birth of not one but two independent nations in August 1947 - India and Pakistan. The rationale for Partition was the two-nation theory, premised on the idea that religious communities constituted nations. Muhammad Ali Jinnah and the Muslim League argued that Muslim interests (or the Muslim nation) could not be safeguarded in an undivided Hindu - majority India. The Congress disagreed, but several factors, including rapidly escalating communal violence, forced the issue and the British government decided to carve out Pakistan by dividing Punjab and Bengal and other contiguous Muslim majority areas. It led to a massive migration of people across the newly created borders both voluntary and involuntary, but mostly the latter.

While the Muslim League had fought for and succeeded in creating what it perceived as a Muslim nation, there were innumerable Muslims who did not buy the argument and stayed behind in India. Their faith in a secular and democratic Indian nation was the strongest challenge to the two-nation theory whose proponents were not just the Leaguers but also those who belonged to Hindu communal parties like the Hindu Mahasabha. Like their counterparts in the Muslim League, they argued for a Hindu rashtra, in which the interests of the Hindu majority would be supreme. While the assassination of Mahatma Gandhi by Hindu communalists was a major blow to communal forces, they have continued to persist and witnessed a revival and consolidation in the last three decades. At the heart of Hindu communal politics espoused by the Bharatiya Janata Party (BJP), the Rashtriya Swayamsevak Sangh and its affiliates is the vision of a Hinduised Indian nation, in which all minorities, particularly the Muslims, are not accepted as full citizens and constantly hounded on account of their allegedly extra-territorial loyalties. This is in sharp contrast to the vision of a secular India espoused by the founding fathers and sought to be preserved by secular, liberal and progressive Indians.

More than any other community or group, the position of Muslims in India, how they are perceived and their self perception, can provide a fair measure of the success or failure of the secular project in post-colonial times. While all minorities, including Christians, Dalits, women and gays are the target of regressive Hindu communal formations, Muslims are singled out as the principal enemy and obstacle to the achievement of the goal of a Hindu rashtra. This is mainly due to the primacy of Partition in the Hindu communal discourse on Indian nationalism from 1947 onwards.

For Muslims in India ${ }^{1}$ the journey from 1947 when they acknowledged their faith in a secular nation to the nineteen-eighties, when the foundations of that faith began to shake, has been a mixed experience. If 1947 was a moment of reckoning when many refused to be swayed by divisive politics and asserted their right to be

* Some parts of this essay are based upon my earlier work, Writing Partition: Aesthetics and Ideology in Hindi and Urdu Literature (Pearson, 2009).

1 The more commonly used terms, Indian Muslims or Nationalist Muslims, are problematic. One rarely comes across the corresponding terms, Indian Hindus or Nationalist Hindus, the underlying assumption being that while Hindus are axiomatically Indian and nationalist, Muslims are not. 
counted as equal partners in the nation-building project, the nineteen-eighties were a second moment when a resurgence of communal forces challenged the belief of secular Muslims in the same nation. Two Hindi novels located in these two moments narrate the seminal role of Muslims in defining the scope and limits of Indian secular nationalism. By studying the two novels together, one can understand how the trajectory of the Indian nation and the minorities continues to be, in some ways, impacted by the Partition and its construction in the post-colonial period.

Rahi Masoom Raza's Adha Gaon², written in the 1960s, explores the Partition of 1947 from the perspective of the residents of a Muslim Shia-dominated village, Gangauli, located in the heart of the United Provinces (now Uttar Pradesh). Manzoor Ahtesham's Sookha Bargad, written in 1986, is set in Bhopal (a city in state of Madhya Pradesh), against the backdrop of the first 1965 war with Pakistan, and narrates the transition of an educated, progressive and liberal Muslim family (the first generation of independent India) to one that becomes insular and narrowminded as communal propaganda gains traction. While Muslim characters in the two novels belong to different social classes, there is nevertheless a continuity that can be traced at many other levels. Both authors are a part of the progressive realist tradition in Hindi literature; both come from progressive Muslim backgrounds and both write in Hindi, a language that has been claimed by Hindu communalists as the exclusive property of Hindus. ${ }^{3}$ Both of them also belong to regions from where numerous Muslims migrated to Pakistan resulting in families getting divided across ideological and national divides. Hence studying the two novels together can provide us an insight into how the Muslim minority attempts to define itself within the larger space of the Indian nation.

Adha Gaon literally means half a village or a divided village and the novel plays on this idea in a variety of ways. In the translator's introduction, Gillian Wright states that the half village in the title refers to the author, Reza's half - the Dakkhin Patti- to which his family belongs. The village Gangauli is actually split between two groups or families of Shia Muslims who reside in two geographically opposed locations, Uttar Patti and Dakkin Patti. Both sides prepare throughout the year to compete for the honor of being the one whose tazias are bigger and more ornate, whose marsias and nohas are more soulful and more evocatively rendered and the one whose expression of pain or karb is more dramatic and cathartic than the others, on the occasion of Muharram. An annual ritual observed by Shia Muslims, Muharram commemorates the martyrdom of Imam Husayn, the grandson of Prophet Mohammad at the Battle of Karbala. Spread over ten days during which Shias remain in

2 Rahi Masoom Reza, Adha Gaon, translated into English by Gillian Wright as The Feuding Families of Village Gangauli (Penguin, 1994 [1966]). All references are from the translated version. Page numbers follow quoted passages in the text.

${ }^{3}$ Languages too have religious identities, according to communalists. The association of Urdu with the Perso-Arabic script and hence Muslims as well as the association of Hindi with the Devnagri script and hence Hindus was clearly the work of communal minded people from about the second half of the nineteenth century. 
a state of mourning, the tenth day, called Ashura, witnesses a re-enactment of the battle when Imam Husayn and his children were killed by the forces of Yazid, the tyrannical ruler. But the split that divides Gangauli in pre-Partition times is innocent and culturally meaningful for the inhabitants when compared to the divisions that emerge after the Partition. Half the village leaves for Pakistan, leaving the other half which remains committed to the homeland. The village gets divided not in a simple way on the basis of ideology, but because communalism creates an environment in which some people succumb to the lure of a better life in Pakistan while others are reluctant and refuse to abandon their land and graves.

Ghazipur and Gangauli function as a template for the nation, with different castes and classes living together, and identifying primarily with their village. Conquests by Muslim princes or their generals have not changed the inter-community relationships. According to local belief, its original name was Gadipuri, which was changed to Ghazipur, when it was taken over by Syed Masood Ghazi, a chieftain of the ruler Mohammad Bin Tughlaq. But names mean little, according to the author/ narrator. "There is no unbreakable bond between names and identity, because if there were then Gadipuri too should have changed when it became Ghazipur, or at least the defeated Thakurs, Brahmins, Kayasths, Ahirs, Bhars and Chamars should have called themselves Gadipuris, and the victorious Saiyids, Sheikhs and Pathans should have called themselves Ghazipuri" (4). Similarly (or conversely) Gangauli was named after a Hindu raja Gang. But even after Nuruddin's Saiyid family established its hold over it, "Gangauli did not become Nurpur or Nuruddinagar" (5). Reza contrasts this with present times when "the residents of Gangauli have been dwindling in numbers and the percentage of Shias, Sunnis and Hindus has been growing (5)."

What is particularly interesting about the social organization of Gangauli is that caste hierarchies that are evident in the Hindu community extend to the Muslims of Gangauli. The Saiyids (like Brahmins) are the highest in the four communities of Muslims, followed by Sheikhs, Pathans and Mughals and then the "lower" caste weavers and Raqis (Sunni traders). This is evident in the notions of ritual purity as well as that of family descent among the Sayyids. While caste is definitely regressive and the basis of exploitation in Adha Gaon, it subverts the overarching communal divide between Hindus and Muslims. Further, by conflating caste and class (both Hindu Thakurs and Rajputs and Muslim Saiyids are the dominant zamindars), Reza shifts the terrain of the conflict from religious identities to class. Kamaluddin, or Kammo as he is called, is stunned at the suggestion of the Aligarh students, who are canvassing for the Muslim League, that Muslims would become "untouchables" if Pakistan was not created (cfr. Hasan 1987: 123-126). "Eh bhai, it looks to me as if it's been a waste of time educating you. What else? If you people don't even know that Bhangis and Chamars are the untouchables. What sort of Bhangis or Chamars do you think we are? And how can anyone who's not an untouchable be turned into one, sahib?" (238).

The repositioning of the relationship between Hindus and Muslims (prePartition camaraderie and post-Partition hostility as in many other Partition narratives) to one in which both communities are fractured along lines of class/caste is a significant counter to the communal divide that engulfs the world outside Gangauli 
and threatens to overrun it also. The communal appeals of both the Hindu fakir and the Aligarh students are countered by the villagers by the local specificities of their existence. When Anwarul Hasan, the Sunni trader's son Farooq, argues for the creation of Pakistan and the threat of Hindu rule, Phunnan Miyan counters him by referring him to their local realities. Firstly he says that if Gangauli is not going to be a part of Pakistan, the issue is irrelevant to him. "Eh bhai, our forefathers' graves are here, our tazia platforms are here, our fields and homes are here. I'm not an idiot to be taken in by your 'Long live Pakistan!'” (149). To Farooq's warning that Hindus would rule them after the British left, he retorts, "you're talking as if all the Hindus were murderers waiting to slaughter us. Arre, Thakur Kunwarpal was a Hindu... and isn't that Parusaram-va a Hindu? When the Sunnis in the town started doing haramzadgi, saying that we won't let the bier of Hazrat Ali be carried in procession because the Shias curse our Caliphs, didn't Parusaram-va come and raise such hell that the bier was carried" (149).

The Quit India movement of 1942 that was marked by violent protests, with government properties and police stations being attacked, also finds its echo in Gangauli but in a somewhat different context. The villagers are fed up with the corrupt Thanedar of the local police station at Qasimabad, Thakur Harnarayan Prasad, who has forcibly extracted contributions from them for the War Fund, meddled in their internal affairs, taken bribes and falsely implicated some of them. Many young men who had volunteered for the War have died or come back maimed and the villagers are incensed with the oppression of the police officials. The Bhars and other retainers of Thakur Prithvipal Singh, the Hindu landlord of Barikhpur and those of Ashrafullah Khan of Salimpur, another Muslim landlord, surround the police station, with the intention of teaching the Thanedar a lesson. Their resentment is local, it is directed against a man whom they see as an oppressor. "In this crowd there were few people who knew the slogan, 'Quit India'. There weren't even people among them who knew what freedom meant. These were the people from whom one-and-a-half amount of land revenue had been taken, from whose fields the grain had been seized, who had been forced to contribute to the war fund, whose brothers and nephews had been killed or were about to be killed in the war, and from whom the police of Qasimabad had been extracting bribes for generations"(164). The crowd includes members from the Chamar community, Baburam Chamar and Gobardhan as well as Harpal Singh the grandson of Thakur Prithvipal Singh and Phunnan Mian's fifteen-year old son Mumtaz. In the firing, Mumtaz, Gobardhan and Harpal Singh are killed, after which the crowd overruns the police station. The Thanedar and all his constables are tied to a tree and burnt to death. The opposition to the police brings together people from different castes and classes. Even though the Shias are able to protect themselves in the aftermath as they are counted as loyalists and "Hakim Sahib had been responsible for the recruitment of one-hundred-and-eleven men", Hammad, who has a personal grudge against Phunnan Miyan, falsely testifies against him and he is "consequently arrested for the martyrdom of Mumtaz."(166). Reza emphasizes the caste and class equations over and above the religious identities in this case too. 
The loyalty of the Hindu "lower" caste Ahirs and Bhars who are patronized by the Shias constantly stands as an obstacle to communal ideology. The alleged threat of Hindu domination by the Muslim League proponents makes little sense to the Saiyids. In fact, it is not the Partition but the abolition of zamindari that constitutes the real threat to their world. The Saiyids are caught between a loyalist position that suited their class interests and the threat of the abolition of zamindari on the one hand, and on the other, their emotional attachment to Gangauli. This is evident in the debate on the issue of whom to vote for in the elections of 1946, between Tannu of Dakkhin Patti, the "black shervanis" (an euphemism for the students from Aligarh who come to seek votes for the Muslim League and appear out of place with their formal dress and polished Urdu in rustic Gangauli) and Hakim Sahib of Uttar Patti. After some quibbling about Jinnah's inaccessibility which Hakim Sahib dismisses as a joke ("When Jinnah Sahib doesn't meet anyone and neither does Allah Miyan, then why don't we vote for Allah Mian?” p. 248), Tannu who has fought in the War and is more educated than the rest, explains to the students in chaste Urdu:

This Patti of loyal government Muslims can't vote for anyone but the League. But you will not be able to take the vote of Musammat Kulsum. She will vote for her "Muntaz". ... He was shot dead at the Qasimabad police station. I was not here at that time but I have heard that he died very bravely... They say that he caught hold of the hem of the shirt of a man running away and said, "Eh, bhaiya, if you go to Gangauli tell my mother I'm dead. This behenchod dard is going to take my life." Perhaps you will not have understood his language because you gentlemen have made the Urdu tongue Muslim. But I swear to God that the language I am speaking now is not my mother tongue. My mother tongue is the one in which Mumtaz sent that message to his mother. (248)

Bhojpuri or Bhojpuri Urdu, the language in which the novel was originally written, draws the ire of Urdu purists even today. ${ }^{4}$ But its local specificity is fundamental to the identity of Gangauli and its residents. When accused of being a traitor to the cause of Islam and Pakistan, Tannu questions the conflation of the two. "'I am a Muslim. But I love this village because I myself am this village... On the battlefield, when death came very near, I certainly remembered Allah, but instead of Mecca or Karbala, I remembered Gangauli'” (249).

But while the argument against voting for Pakistan can be easily demolished, the more difficult question of zamindari remains. After all the Congress was clear that zamindari had to be abolished. This meant that the power equations of Gangauli would change and the Saiyids would lose their hold on the "lower" castes

${ }^{4}$ According to some the term "Bhojpuri Urdu" itself is an anomaly. The sophisticated Urdu that belongs to urban and educated speakers from Lucknow, Aligarh and Delhi has little in common with the language of the villagers in Gangauli. Their unpolished language, peppered routinely with abuses and curses is a distinct marker of their identity. 
whom they had exploited for a long time. Yet even this loss cannot be enough reason to abandon one's home. In the final analysis, the tragedy of Gangauli is that an older social and economic structure collapses with the coming of Independence. Sukhram, a "lower" Hindu caste retainer of the Saiyids and his son Parusaram suddenly acquire political power when they are patronized by the Congress party. As Husain Ali Miyan bursts out angrily: "Sukhram-va's son Parusaram-va has become a political leader the moment he's stepped out of jail. He's roaming around wearing a Gandhi cap and making speeches everywhere that times have changed, now the zamindars' force and cruelty won't work!'(265). Even between the Saiyids the hold over land becomes a contested issue. Alienation within families leads to Mighdad even redefining his relationship with his own father. "I don't know about his being any father of mine,' said Mighdad. 'He's a zamindar and I'm a cultivator" (268). When several of them try to grab a piece of land illegally, Mighdad simply goes and ploughs it, staking his claim as a tiller. As Parusaram tells him, "by putting your hands to the plough you have broken your connections with the zamindars" (268). As the Shia landowning families lose power and prestige, their young men migrate to Pakistan in search of better opportunities leaving behind older family members, wives, and children. The author/ narrator does feel nostalgic about the older order but he also recognizes that the change is inevitable and to an extent empowering for the subalterns even though he may not approve of the opportunist Parusaram who suddenly becomes powerful after joining the Congress. Reza is perceptive enough to recognize that the pace of change in the social and political order did not necessarily imply a greater consciousness among the "lower" castes. "He [Parusaram] really didn't know why he had accepted Gandhiji as his leader... Perhaps more than Gandhiji he needed the Gandhi cap, due to which government officials had begun to fear him, and due to which his status had increased and income too" (269). In fact after getting elected, Parusaram becomes exceedingly corrupt and flaunts his power and wealth before the Mians. He gets embroiled in the internal conflicts of the Shia families and when challenged by Phunnun Mian, he gets him killed. Reza shows how the corrupt local Congress workers use their political power to enhance their personal interests rather than for amelioration of other victimized groups.

Given the class interests of the Shia landlords, they are not sympathetic to the democratic, socialist impulse of the Congress that abolishes zamindari. For them, Muharram becomes a symbol of their own pain — both the separation of families and the dissolution of zamindari. With the impending loss of their zamindaris, the Saiyids begin to gradually build alliances through marriages with non-Saiyid families. Mighdad was ostracized by his own family and the Saiyids for marrying a barber's daughter, Saifunya. But when she dies, his father Hammad wants to reconcile with him so that the land can be worked jointly again. "The wheel of zamindari tradition turned. The barbers came... A grave was dug a short distance away from the family cemetery, and the Saiyid gentlemen set out carrying the bier of the barber's daughter" (287). A new social order in which the caste hierarchies among the Shias have been subverted comes into existence. Blood lines can no longer remain pure. Saiyid girls are married off to non-Saiyid and even illegitimate boys. 
And many young men migrate to Pakistan in search of a better life. And Gangauli is irreversibly altered.

Yet the communal canker fails to take root in Gangauli. When the old enmity between Thakur Prithvipal Singh of Barikhpur and the Khan Sahib of Salimpur flares up, some outside communal elements try to take advantage. They infiltrate the ranks of Thakur Prithvipal's retainers and the Hindu fakir incites the crowd against the Muslims. "It [the crowd] thought that Muslims are Muslims and the only difference between the Muslims of Salimpur and Barikhpur was that the Salimpur Muslims were rather far away and those of Barikhpur were nearby" (274). But they are shocked when Prithvipal Singh turns against them when his "own" Muslims are threatened. He not only chases them away, but even threatens to beat up his own Muslims when they ask his permission to leave Barikhpur for Muslim majority areas like Mubarakpur and Bahadurganj.

Reza constructs Gangauli as an oasis in the midst of the communal violence that breaks out in places like Calcutta, Noakhali, Lahore and Bihar. News of the terrible massacres of Muslims keeps coming but the Saiyids and other Muslims refuse to succumb to the pressure of communal ideology. Even the blatant prejudice against Muslims, does not make them despair. When a martyrs' memorial is unveiled at Qasimabad police station to honor those killed in the 1942 movement, and Balmukund Varma, a Congress leader, keeps on praising the role of Haripal and Gobardhan, and their "sacrifice to the Motherland", Phunnan Mian interrupts him. " "Eh, sahib! A son of mine was killed here too. It looks like no one told you his name. His name was Muntaz!' Having finished what he had to say, Phunnan Miyan turned to look at the crowd. His head was held higher than anyone's" (268).

Muslim League propaganda is rejected by the villagers, Pakistan means nothing to them, Gangauli is all. In fact Raza shows how for the villagers, even the idea of a national identity, that supersedes their local identity is inexplicable. Hence while Pakistan is a ridiculous idea, the Indian nation too means little. Pakistan is linked to the abolition of zamindaris and hence seen as something that robs them of their rightful privileges and power. Though the argument seems somewhat illogical, Sakina, one of the Saiyid ladies, lashes out at Pakistan for their impoverished plight. " 'If that wretched Pakistan hadn't been made, zamindari wouldn't have been finished. Gandhiya said, "All right, Miyans, you've made your Pakistan, now go to hell...zamindari's over" (300).

While the novel does highlight the Hindu communal threat in 1947, it does not show the Muslims backing off. While the circumstances of the Saiyids may have pauperized them, they do not take the easy way out by accepting the argument for Pakistan. They try to reconcile themselves to their straitened circumstances, unwilling to abandon their homes and village. They make what seem to them humiliating compromises with the "lower" castes, and struggle to find the means to sustain themselves. But not one of the principal characters is ideologically or emotionally invested in the creation of Pakistan. While they do not see themselves consciously as equal citizens of an independent Indian nation, their commitment to their village and opposition to communal forces can be read as a positive aspect of their self perception. This is something that is reiterated 
by the narrator/author, Rahi Masoom Reza himself, in the unusual introduction that he inserts towards the end of the novel to mark the transition from one age to another. "My bonds with Gangauli are unbreakable. It's not just my village, it's my home... And I give no one the right to say to me, 'Rahi! You don't belong to Gangauli, and so get out and go, say, to Rae Bareli.' Why should I go, sahib? I will not go."(290-291) Even in his most impassioned moment, Reza cannot bring himself to say "Pakistan", a minor detail that reveals his complete aversion to the very idea (cfr. Ansari 1999).

In his book Remembering Partition, Gyanendra Pandey has cited the insertion of this introduction as a "challenge to the claims of nationalism and nationalist historiography" because it "subverts the rules of the writing of novels, and of nationalist thought" (200). Pandey's assumption that nationalism is being challenged is in fact not borne out through a careful reading of the text. Firstly, Reza himself provides an explanation for the introduction in the middle of the text: "The fact is that now our story has come to a place where one age ends and another begins. And doesn't every new age demand an introduction?” (290). The narrative is split neatly by the introduction between the period prior to Partition and the one that comes after it. While in the former Partition/abolition of zamindari is troubling everyone, in the post-Partition period, it is a settled issue, and the reality of what has happened has finally seeped in. Secondly, Reza's central statement about his bonds with Gangauli is made in the context of a Hindu communal assumption about Muslims, viz.: "The Jan Sangh says that Muslims are outsiders" (290). Hence what Reza is questioning is the Hindu communal position that Muslims are aliens in India, a position that links religion with nation and not nationalism itself, as Pandey suggests. The critique of nationalism as a statist ideology by Pandey and others like Homi Bhabha, elides the idea of a secular nationalism that is implicit in Reza's critique.

If Adha Gaon locates Muslims within the "moment" of Partition, Sookha Bargad, takes up the story several years later. Though the novel was published in 1986, it is set against the backdrop of the 1965 war with Pakistan. It is possible to trace a link between these two years with regard to the re-emergence of Hindu communalism. The Nehruvian era that was marked by a spirited and robust secular politics was followed by a slow re-emergence of Hindu communal forces, particularly around the time of the 1965 war during which Muslims in India were demonized for their alleged sympathies with the enemy. Identity politics during the 1970s and the early 1980s led to a strengthening of communal forces and the consequences were reflected in the demand for Khalistan, the Shah Bano case and the Ram Janmbhoomi issue that culminated in the destruction of the Babri Masjid in 1992. Sookha Bargad is set in the aftermath of the 1965 war, but in some ways it is a narrative of the 1980s, when the anti-Muslim sentiment had severely dented the secular forces.

While Reza's Saiyids may have countered the communal challenge by recourse to their identification with Gangauli and their Hindu neighbors around 1947, in Sookha Bargad Rashida and Sohail have to contest the enemy in a different form and context. Wahid Khan, their father, like the narrator/ author of $A d h a$ Gaon, had refused to leave his home in Bhopal to migrate to Pakistan, with the rest of his family. An educated and liberal-minded lawyer, Wahid Khan has invested in 
a modern education for his children. A secular nationalist to the core and an atheist, he consistently refuses to allow his "religious" identity to define him in any way (cfr. Naim 1999). Thoroughly disgusted with how religion was used to distort and mutilate human values, he chose to practice "secular" law and fight for what was morally right, even though it meant going against his family elders. His children Rashida and Sohail have imbibed his liberal values and strongly argue against the communal beliefs within their extended family and the Muslim community. ${ }^{5}$ Their closest friend is the Hindu boy, Vijay, who also shares their beliefs and is equally committed to the secular cause. Interestingly, his refugee parents were saved by Muslim friends during the Partition riots, and far from harboring any grudge against Muslims, Vijay is strongly opposed to any communal stereotyping. Sohail and Rashida refuse to succumb to the pressure of Muslim communal elements who try to play upon feelings of victimization. Sohail derives strength from Vijay who shares his views. Both recognize that the fault lies with their own communities. When Sohail is critical of Muslims who put religion above country and humanity, Vijay accepts that it is the majority community that is responsible for the fear and ghetto-isation of Muslims. However what the novel narrates is the erosion of their faith in the possibility of countering communal forces, both Hindu and Muslim.

Wahid Khan's commitment to secular practice and his refusal to participate in the Islamic rituals because of his rational approach, draws the ire of both his extended family and the Muslim community at large. ${ }^{6}$ The extended family and the community ostracize him socially and while he is willing to pay the cost, it is not easy for his children. In their school going years, Rashida and Sohail feel uncomfortable with their alienation, but Wahid Khan constantly tries to convince them about the moral and ethical bankruptcy of those family members whose vision is narrow and sectarian. As young adults they are exposed to communal ideas of both sides and the novel represents their conflicts sensitively.

Their faith in Wahid Khan's secular values, however, comes under severe pressure during the war with Pakistan. One of the consequences of Partition that continues to find resonance till today is the tragedy of divided families. While families try to keep up the connections, in times of war and hostility between the two countries Muslims in India are conveniently targeted by Hindu communalists. The natural interest in the fate of their relatives across the border is deliberately misinterpreted as sympathy for the enemy. Their listening to Radio Pakistan for

${ }^{5}$ For a first person account of how Muslims accept India as their country despite allegations about their disloyalty see Salman Khurshid 2014.

6 "Those who got the worse of it, both in India and Pakistan', commented a well-known Urdu writer, 'were the honest, sincere Nationalist Muslims who, in the eyes of Hindus, were Muslims, and vice versa. Their sacrifices were reduced to ashes. Their personal integrity and loyalty were derided. Their morale was shattered like a disintegrating star; their lives lost meaning. Like the crumbling pillars of a mosque they could neither be saved nor used." Shorish Kashmiri, Boo-i gul Naala-i dil Dood-i Chiragh-i Mehfil, cited in Hasan 1993: 2/145. . jan.ucc.nau.edu/sj6/hasanprologueintro.pdf. Accessed 15 December 2017. 
news is projected as irrefutable proof of their subversive activities. Rashida, whose paternal aunt lives in Karachi and close maternal relatives in Lahore, is naturally worried about their safety, even though she has never met them. But she is also troubled by why she should be interested in the wellbeing of people who belong to the enemy nation. Rashida's inner conflict reveals how complex Muslim Indian identity is and the challenges of retaining a secular outlook when one is constantly being suspected of extra-territorial sympathies.

A second important issue raised in the novel is marriage across the HinduMuslim divide. While both Vijay and Sohail believe that such relationships would be a significant counter to communal sentiments, their own personal relationships fail in the face of social pressure. Sohail's relationship with Geeta Sharma, a Hindu girl comes to a premature end when her parents force her to get married to a Hindu boy. And Rashida, though committed to Vijay, finds it impossible to resist the pressure of her family after the death of her father. She is forced to break off with Vijay, though she refuses to get married to the educated, well-off Hamid who is settled in Pakistan.

Social (and communal) opposition to a Hindu-Muslim relationship is rooted in racist and patriarchal ideologies and communalists build upon these to create insular identities. The idea that Hindus and Muslims are two races that come from different stocks is a myth perpetuated by both Hindu and Muslim communalists. Given that patriarchy is also an integral part of communal ideology, a Muslim boy converting and marrying a Hindu girl (or vice versa) is considered a victory of Islam (or Hinduism in the opposite case) and Muslims (or Hindus) in a perverse way. It is significant that some traces of this approach can be found in the educated, liberal Rashida also. In her private moments she recalls how when Salim, a distant cousin, converted and married a Hindu girl, it was greeted with great joy, not just by the fanatics but also by her. Rashida, as a woman, is unable to completely distance herself from the hold of patriarchal and communal forces, despite her best efforts. As a man Sohail has greater agency, but in the absence of a livelihood, and completely disillusioned after the breakup with Geeta, he breaks down. The novel ends with his inability to reconcile to opposing pulls — trying to become a pious Muslim and relapsing into a state of drunkenness by turns.

The two novels problematize the issue of a national identity for Muslims in India after the creation of Pakistan. Characters in both novels oppose the communal discourse that equates Muslims and Pakistan and emphatically insist on their rights to their homes. While the Saiyids in Reza's novel cannot imagine a world outside Gangauli, Abdul Wahid Khan is an educated, rational, liberal Muslim who considers himself to be an equal citizen in secular India. Home for him is the entire nation, the space that he believes that he shares with all his fellow countrymen. In one sense he extends the argument put forward by Phunnan Mian who demands that his son Mumtaz be honored along with the Hindu martyrs of 1942. As a rational humanist, he ridicules his own community for its insularity and narrow thinking. However Partition continues to cast its long shadow even after several years. While the Hindu communal forces carry on from 1947 in their demonization of Muslims as treacherous aliens who properly belong to the other side of the border, the Muslim 
communalists build on the insecurity of the community to propagate a narrow, conservative Islamic identity that needs to be nurtured. Secular-minded Muslims like Wahid Khan and his children exist in a state of siege, cornered by communalists of both hues, fighting what seems to be a losing battle. Even the Saiyids seem better off in Gangauli despite their losses.

By putting together two moments from the recent history of Muslims, one can trace the trajectory of national identities and nation formation, in the shadow of Partition. What has Partition meant for Muslims in India, what has been its long term fallout, why do Muslims continue to bear the brunt of the actions of their co-religionists even though many of them did not support the demand for Pakistan and what does it mean to be secular and a Muslim in recent times when Hindu communal forces are spreading mayhem and blatantly discriminating against the minorities? These are some of the questions raised by Rahi Masoom Reza and Manzoor Ehtesham. On a broader level, the novels inscribe the centrality of Muslims in India to the conception of a secular Indian nation and the challenges that threaten to derail it even many years after Partition. 


\section{REFERENCES}

Ansari, Nasim. Choosing to Stay: Memoirs of an Indian Muslim Translated by Ralph Russell. City Press, 1999.

Ehtesham, Manzoor. Sookha Bargad. Rajkamal, 2003 (1986).

Hasan, Mushirul. 'Nationalist and Separatist Trends in Aligarh', 1915-1947, in A.K. Gupta ed., Myth and Reality: The Struggle for Freedom in India, 1945-47. Manohar Publishers, 1987, pp. 123-126.

(ed.) India Partitioned. Oxford University Press, 1993. 2 vols.

Hyder, Qurrutulain. Aag ka Dariya. Kali for Women, 1998.

Khurshid, Salman. At Home in India: The Muslim Saga. Hay House India 2014.

Naim, C.M. Ambiguities of Heritage: Fictions and Polemics. City Press, 1999.

Pandey, Gyanendra. Remembering Partition: Violence, Nationalism and History in India. Cambridge University Press, 2001.

Prakash, Bodh. Writing Partition: Aesthetics and Ideology in Hindi and Urdu Literature. Pearson, 2009.

RezA, Rahi Masoom. Adha Gaon (1966). Translated into English by Gillian Wright as The Feuding Families of Village Gangauli. Penguin, 1994. 
